\title{
Neutral red with photoinactivation in the treatment of herpes genitalis
}

\author{
A. P. C. H. ROOME, ${ }^{\star}$ A. E. TINKLER, A. L. HILTON, D. G. MONTEFIORE^キ, \\ AND D. WALLER \\ From the Departments of Microbiology and Venereology, Royal Infirmary, Bristol, and the \\ University of Bristol
}

The present treatment of acute herpes genitalis is unsatisfactory. Many kinds of treatments have been employed, including the use of specific anti-viral agents such as idoxuridine as topically-applied preparations, in various bases ranging from simple ointments to 100 per cent. dimethylsulphoxide. Opinions as to the efficacy of idoxuridine differ, some workers reporting favourably (Prusoff, 1967) and others finding it of little value ( $\mathrm{Ng}$, Reagan, and Yen, 1970). In the most severe cases, it has even been suggested that systemic treatment with cytosine arabinoside would be justified (Juel-Jensen and MacCallum, 1972), although this treatment would hardly seem suitable for routine use.

Many other non-specific treatments have been tried, including the use of antibiotic creams, hydrocortisone creams, and analgesic creams: in general, however, the position seems to have changed remarkably little since the beginning of the 19th century (Bateman, 1813), when the recommended treatment comprised dry dressings, cold creams, talcum powders, and saline baths.

It has been known for some years that Herpesvirus hominis will form complexes with certain vital dyes such as neutral red, proflavine, and toluidine blue, and that these complexes are subject to rapid biological inactivation when exposed to visible light in the presence of molecular oxygen (Wallis and Melnick, 1964). This led to interest in the possibility of using this system for the treatment of superficial herpetic infections, and numerous studies have been undertaken in animals as well as in man.

The results of treatment using this system have been variable: in animal studies, mainly using a model system involving herpetic keratitis in the rabbit, some workers have reported satisfactory results (Moore, Wallis, Melnick, and Kuns, 1972),

Received for publication June 11, 1974

*In receipt of Grant No. 277, Medical Research Committee, United Bristol Hospitals

†Present address (for reprints): Public Health Laboratory, Gloucestershire Royal Hospital, Southgate Street, Gloucester GL1 1UD ¥Present address: Department of Medical Microbiology, University of Ibadan, Nigeria while others have found the treatment to have little if any beneficial effect (Varnell and Kaufman, 1973; Thomas, Dunlap, and Rich, 1973). Reports of treatment of patients with genital herpes have been encouraging (f. Amer. med. Ass., 1971), but findings have often depended heavily on self-assessment of progress by patients suffering from recurrent herpes, and there was evidence of a 'placebo' effect in some of the reports (Wallis, Melnick, and Kaufman, 1972). It has been recognized that the true place of photodynamic inactivation in the treatment of herpes infections will be determined only by further controlled studies (Brit. med. F., 1974).

It thus seemed worthwhile to try to determine the value of treatment with neutral red and photoinactivation in patients with genital herpes, by comparing the progress of a group treated with this dye with that of a group treated similarly with phenol red-a non-photoactive dye (Wallis and others, 1972). Because of the self-limiting nature of the infection, and the influence of previous exposure to either Type 1 or Type 2 Herpesvirus hominis on the severity and duration of lesions (Kaufman, Gardner, Rawls, Dixon, and Young, 1973b; Nahmias, Josey, Naib, Luce, and Duffey, 1970), it was recognized that both antibody status at the time of first attendance, and the duration of symptoms before attendance would have to be taken into account.

\section{Patients and methods}

\section{(1) Patients}

Persons presenting at the Special Treatment Clinic, Bristol Royal Infirmary, who were clinically diagnosed as suffering from herpes genitalis, were asked if they would be willing to take part in the trial, the nature of which was fully explained to them, together with the requirement for returning for assessment on a number of occasions. Many of the male patients felt that they were unable to make the required number of visits; there was also a substantial number of men who attended with relatively mild lesions which were already beginning to heal spontaneously. These factors resulted in a preponderance of women being admitted to the trial. 
Treatment was started on the basis of the clinical diagnosis, and patients from whom herpes virus was not isolated were later excluded from consideration. Thus the patients finally admitted to the trial were all virologically proven cases of herpes infection.

\section{(2) Treatment}

Patients were randomly allocated to either the 'Treatment' (neutral red) group, or to the 'Placebo' (phenol red) group. The neutral red (Gurr) was made up as a 0.1 per cent. aqueous solution, and the phenol red (B.D.H.) in similar concentration, so that the colours of the two solutions were closely similar. The solutions were sterilized and dispensed in $30 \mathrm{ml}$. volumes in blackpainted universal bottles, which were numbered according to the random allocation roster. The code containing the key to which solution was being applied to each patient was kept sealed until the end of the trial; thus all observers were unaware of the treatment group of any patient during the course of the trial.

The dye solution was liberally applied to the affected area by means of a soaked gauze swab, which was kept in place for 10 minutes. Initially it had been intended to remove the tops of any vesicles so that the dye would reach the base of the lesions: in the event, it was found that all patients who had vesicles also had ulcers, and that the area was so tender that removal of vesicle tops was unacceptable.

After the application of the dye, the area was exposed to the light from a 15 watt fluorescent tube, at a distance of about $6^{\prime \prime}$ from the lesions, for 15 minutes. Patients were given the remainder of the solution, and were asked to repeat the application once more within 4 to 12 hours, and to expose the treated area to light, using either a fluorescent or tungsten lamp as available, the light being placed as close to the affected area as possible. As would be expected, the patients used tungsten table lamps.

As far as possible, all other treatments were avoided: but two patients received penicillin for concurrent gonorrhoea, and five patients with marked secondary bacterial infection received either systemic sulphonamide (two patients) or cotrimoxazole (three patients). There was little evidence that these had any discernible effect.

\section{(3) Virus isolation}

Material was taken from the lesions with cotton-wool swabs at the first attendance before any treatment had been given, and was sent to the laboratory in milk-saline transport medium. It was inoculated into tissue cultures of human embryo fibroblast cells, Vero cells, and Hep-2 cells. Isolation and identification of virus strains were by standard methods; typing of herpes strains was by observation of the type of cytopathic effect produced in B.H.K.-21 cells (Smith, Peutherer, and Robertson, 1973). Further material was taken, and similarly handled on the 1st, 2nd, 3rd, and 7th days after starting treatment: if one of these days fell at the week-end when the clinic was closed, the sample was taken on the following day.

In addition to vulval material, cervical samples were taken from twelve of the women at their first attendance.

\section{(4) Blood samples}

The diagnosis of 'recurrent' or 'primary' infection was based on the presence or absence of complement-fixing antibodies to Herpesvirus hominis in a blood sample taken at the first attendance.

\section{(5) Assessment of patients}

At the first attendance, a history was taken of the number of days before attendance that the lesions had first appeared, and of previous episodes of either herpes genitalis or herpes labialis. A standard proforma was used to record subjective symptoms (pain, itching, burning, or tingling) and observed signs (redness, swelling, vesicles, ulcers, adenitis, and secondary bacterial infection). These findings were also recorded at each of the subsequent attendances $1,2,3$, and 7 days after starting treatment. On the basis of these findings an assessment was made as to whether the patient was 'better', 'unchanged', or 'worse'. An assessment as 'better' meant that there was obvious subjective and objective improvement, but does not indicate that all lesions were completely healed.

\section{Results}

A total of twenty patients (16 women and 4 men) were admitted to the trial with virologically confirmed herpes infections; seventeen were due to Type 2 virus, and three to Type 1 . Three patients gave a history of previous known herpetic infections, but nine patients actually had antibodies present in their serum at first attendance; six of the nine had had symptoms for less than 5 days before attendance (see Table II, below).

Cervical swabs were taken, at first attendance only, in twelve of the sixteen female patients, although only the accessible skin lesions were treated. Herpes virus was isolated from the cervical swabs from eight of the twelve; the sample from one patient was contaminated with antibiotic-resistant bacteria. Thus the presence of vulval herpes is likely to be accompanied by cervical infection. The male patients all had penile lesions.

One patient did not attend for adequate assessment, leaving nineteen patients ( 11 in the 'Treatment' group and 8 in the 'Placebo' group) who could be validly compared.

Table I shows the overall results for the two groups, on the basis of the mean number of days between first attendance and assessment as 'better'. There is no difference between the two groups, the mean time for the 'Treatment' group being $4 \cdot 6$ days, and for the 'Placebo' group 5.0 days. None of the

TABLE I Number of days taken for lesions to improve after treatment

\begin{tabular}{|c|c|c|}
\hline Group & Neutral red (11) & Phenol red $(8)^{\mathrm{a}}$ \\
\hline $\begin{array}{l}\text { Mean number of days from } \\
\text { first attendance for lesions } \\
\text { to be assessed 'better" }\end{array}$ & $\begin{array}{l}4 \cdot 6 \\
\text { SD } 2 \cdot 5\end{array}$ & $\begin{array}{l}5 \cdot 0 \\
\mathrm{SD} 2 \cdot 8\end{array}$ \\
\hline
\end{tabular}

aOne patient did not att $\in$ nd for adequate assessment to be made. $\mathrm{SD}=$ Standard deviation 
patients experienced particularly rapid relief of pain, which in general continued for two or three days after treatment was started.

There was no evidence that the neutral red treatment led to more rapid elimination of infective virus: among the patients treated with neutral red, herpes virus could be isolated for a mean duration of 4.0 days (standard deviation 2.5) while for the phenol red group the period was $4 \cdot 7$ days (standard deviation 3.7).

Since progress might well be affected by the duration of illness before attendance at the clinic, and also by the immune status of the patient-that is, whether the attack was a primary infection or not-the results were also considered under these headings. Table II shows that there was no marked preponderance of either 'Treatment' or 'Placebo' patients in any of the categories considered. Despite the small numbers, there was an indication, as might be expected, that patients with no previous antibodies experienced a more protracted course from the time of first attendance than those with antibody, and that patients who first attended some days after the onset of their illness required fewer additional days to recover than those who attended soon after the appearance of their first symptoms. There is, however, no evidence that treatment with neutral red had any influence on the duration of the illness, nor did it result in more rapid relief of pain.

\section{Discussion}

The results of this study do not confirm the favourable reports of treatment by photodynamic inactivation recorded by other workers (Felber, Smith, Knox, Wallis, and Melnick, 1973; Friedrich, 1973). Under the conditions of this trial, no benefit could be detected from treatment with neutral red, when compared with treatment with the placebo dye, phenol red. Patients in the present study did not experience rapid and dramatic relief of pain, as has been reported in other trials of photoactive dye treatment (Kaufman, Gardner, Brown, Wallis, Rawls, and Melnick, 1973a). In fact, the condition of five patients who had been treated with neutral red and photoinactivation actually deteriorated during the first day or two after treatment; all of these lacked pre-existing antibodies against herpesvirus.

It would appear that the major factor apparently determining the progress of our patients was whether or not they had previously been exposed to herpes infection; it is recognized that patients with recurrent infections tend to have milder and shorter illnesses than patients with primary infections (Rawls, Gardner, Flanders, Lowry, Kaufman, and Melnick, 1971).

We have, therefore, failed to demonstrate the efficacy of neutral red therapy. Our method differed slightly from that of other workers in that, owing to the pain involved, we did not remove the tops of existing vesicles, but since all patients who had vesicles also had ulcers at the time of treatment, and intact vesicles were few, we do not feel that this can account for our failure to demonstrate any beneficial action. Should an effective topical treatment become available, the finding that approximately 75 per cent. of patients with vulval lesions also have infection of the cervix, would indicate that treatment of both sites would be required, and that the agent used would thus need to be reasonably simple to apply intravaginally.

\section{Summary}

A clinical trial was undertaken to compare the efficacy of neutral red photodynamic inactivation treatment of genital herpes infections with that of a nonphotoactive dye, phenol red, as a control. In a series of nineteen patients with virologically proven herpes genitalis who were adequately followed, eleven were

TABLE II Results of treatment according to length of illness and presence of antibodies at first visit

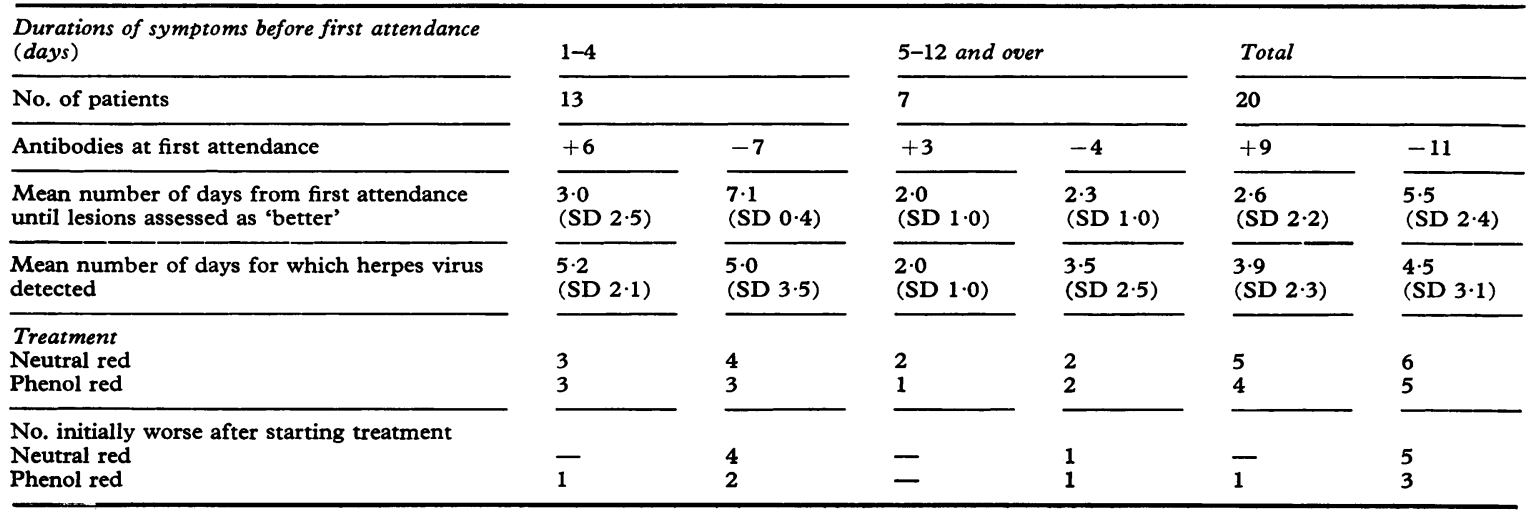

$\mathrm{SD}=$ Standard deviation 
treated with neutral red, and eight with phenol red; no difference in response to therapy was found between the two groups, and it is concluded that under the conditions of this trial neutral red with photoinactivation was not effective in the treatment of acute genital herpes infections. Approximately 75 per cent. of those with vulval lesions also had concurrent cervical infection, so that an effective topical treatment would need to be applicable to both anatomical sites.

We should like to thank Sister M. M. Moore, Mr. W. J. Howells, Mr. A. G. Martin, and the other members of the staff of the Special Treatment Clinic, for all their assistance in the conduct of this trial.

\section{References}

Bateman, T. (1813) 'A Practical Synopsis of Cutaneous Diseases', p. 234. Longman, Hurst, Rees, Orme, and Brown, London.

Brit. med. F. (1974) 2, 461

Felber, T. D., Smith, E. B., Knox, J. M., Wallis, C., and Melnick, J. L. (1973) f. Amer. med. Ass., 223, 289

FRIEDRICH, E. G. (1973) Obstet. and Gynec., 41, 74

f. Amer. med. Ass. (1971) 217, 270

Juel-Jensen, D. E., and MacCallum, F. O. (1972) 'Herpes Simplex, Varicella, and Zoster', p. 159. Heinemann, London

KaUfMaN, R. H., GardneR, H. L., BRown, D., Wallis, C. Rawls, W. E., and Melnick, J. L. (1973a) Amer. $\mathcal{F}$. Obstet. Gynec., 117, 1144

- - - RAwls, W. E., Dixon, R. E., and Young, R. L. (1973b) Cancer Res., 33, 1446

MOORE, C., WALlis, C., MelNiCK, J. L., and Kuns, M. D. (1972) Infect. and Immun., 5, 169

Nahmias, A. J., Josey, W. E., Naib, Z. M., Luce, C. F., and Duffey, A. (1970) Amer. F. Epidem., 91, 539
Ng, A. B. P., Reagan, J. W., and Yen, S. S. C. (1970) Obstet. and Gynec., 36, 645

PRusoff, W. H. (1967) Pharmacol Rev., 19, 209

RaWls, W. E., Gardner, H. L., Flanders, R. W., LOWRY, S. P., KaUfMaN, R. H., and MelNiCK, J. L. (1971) Amer. F. Obstet. Gynec., 110, 682

SMith, I. W., Peutherer, J. F., and Robertson, D. H. H. (1973) Brit. F. vener. Dis., 49, 385

Thomas, J. V., Dunlap, W. A., and Rich, A. M. (1973) Brit. F. Ophthal., 57, 336

VARNELl, E. D., and KAUfMAN, H. E. (1973) Infect. and Immun., 7, 518

Wallis, C., and MelniCK, J. L. (1964) Virology, 23, 520

- - - and Kaufman, R. H. (1972) Clin. Obstet. Gynec., 15, 939

Photoinactivation par le rouge neutre dans le traitement de l'herpès génital

SOMMAIRE

Un essai clinique fut entrepris pour comparer, dans les infections herpétiques génitales, l'efficacité du traitement d'inactivation photodynamique au rouge neutre avec, comme témoin, celui d'un colorant non photoactif, le rouge phénol. Sur une série de 19 malades, atteints d'herpès génital prouvé virologiquement et convenablement suivis, 11 furent traités par le rouge neutre, 8 par le rouge phénol; aucune différence ne fut trouvée dans la réponse thérapeutique des deux groupes et l'on conclut que, dans les conditions de cet essai, la photoactivation par le rouge neutre ne fut pas efficace dans le traitement des affections herpétiques génitales aigües. 75 pour cent environ des cas avec lésions vulvaires avaient également une infection cervicale, si bien qu'un traitement local efficace est nécessaire vis-à-vis de ces deux localisations anatomiques. 